\title{
THE EFFECT OF 6-MERCAPTOPURINE ON PRIMARY AND SECONDARY IMMUNE RESPONSES *
}

\author{
By ROBERT SCHWARTZ, $\dagger$ ANNA EISNER AND WILLIAM DAMESHEK
}

\author{
(From the Blood Research Laboratory, New England Center Hospital, and the Department of \\ Medicine, Tufts University School of Medicine, Boston, Mass.)
}

(Submitted for publication February 10, 1959; accepted April 2, 1959)

The immune response may be considered as a complex metabolic process initiated by an antigenic substance and resulting in the formation of highly specific proteins. The mechanisms underlying this response are not clearly understood, but it is evident that the nucleus of antibody forming cells as well as their cytoplasm participate (1). Following the administration of antigenic material to experimental animals, striking morphologic and biochemical changes occur within the antibody forming tissues (2). The structural alterations include hypertrophy and cellular proliferation, while the biochemical changes are reflected by increased nitrogen, desoxyribose nucleic acid (DNA) and ribonucleic acid (RNA) contents of these tissues. These changes occur during the primary and secondary immune responses ${ }^{1}$ as well as after the stimulation of regional lymph nodes by heterografts (3). The increase in DNA content is largely due to cell multiplication, which begins within 48 hours after the injection of antigen. Increases in RNA, however, occur somewhat later, and the peak of cellular RNA concentration coincides closely with the peak of serum antibody titer $(4,5)$. Studies such as these indicate that the formation of antibody is closely linked to nucleic acid metabolism.

In a previous publication we have shown that

* Aided by grants from the United States Atomic Energy Commission Contract AT(30-1) 2032 and the United States Public Health Service (National Cancer Institute) No. CY 4168.

$\dagger$ Under tenure of a United States Public Health Service Fellowship No. HF-7166(C).

1 The primary response is an immunological reaction which follows the first exposure to an antigen. It is characterized by the relatively slow appearance of small quantities of antibody in the blood. The secondary response is an immunological reaction which occurs after re-exposure to an antigen. In contrast to the primary response, this reaction is rapid, large quantities of antibody are formed and antibodies are found in the blood over a long period of time. a purine analog, 6-mercaptopurine (6-MP), prevents the formation of antibodies by hyperimmunized rabbits (6). In this report we will present further studies concerning the mechanism of action of 6-MP on the immune responses of rabbits. These responses were studied in vivo by determining rates of antigen disappearance using the isotope technique of Talmage, Dixon, Bukantz and Dammin (7) and by measuring antibody appearance by the ammonium sulfate fractionation method of Farr (8) and the tannic acid hemagglutination of Stavitsky (9). It will be shown that 6-MP can completely block the primary immune response, while that dose of the drug which prevents the appearance of the primary response delays, but does not prevent, the onset of the secondary response.

\section{MATERIALS AND METHODS}

Animals. Healthy white New Zealand rabbits obtained from a nearby supplier and weighing about $2 \mathrm{Kg}$. each were used. The animals were housed in individual cages in an air-conditioned room. All rabbits were maintained on Purina Rabbit Chow ${ }^{\circledR}$ and water ad libitum.

Radioisotopes and antigens. Radioiodinated human serum albumin (HSA-I) was obtained from Abbott Laboratories. This material is supplied in vials containing about $1 \mathrm{ml}$. of a 1 per cent solution of human serum albumin conjugated with $500 \mu \mathrm{c}$. of I-131. "Loosely bound" radioiodine activity of this preparation is less than 1 per cent, and the appearance of free iodide during storage is negligible. Human serum albumin (HSA) was obtained from the Protein Foundation Laboratories (Lot No. HAB51CH). This material was isolated from human serum by the cold ethanol fractionation method of Cohn, and was supplied to us as a dry powder. Solutions of the desired concentration were prepared in 0.15 M saline.

Isotope detection. Isotope activity was detected in a well-type scintillation counter which affords reproducible counts better than \pm 3 per cent. The detector was standardized daily against a long-lived nuclide, Cs 137. I-131 counts were made directly from measured amounts of serum, usually $1.0 \mathrm{ml}$. In order to eliminate counting 
errors due to geometric variations of the sample, those tubes which contained less than this amount of serum were diluted to $1.0 \mathrm{ml}$. with $0.15 \mathrm{M}$ saline. Serum I-131 activity of the various samples was corrected for individual variations in blood volume, assuming a blood volume of $8 \mathrm{ml}$. per $\mathrm{Kg}$. of body weight. Of those sera which contained radioactivity, no sample had counts less than twice that of the background radioactivity.
6-Mercaptopurine. This compound was supplied as an amorphous yellow powder, insoluble in water, but quite soluble in dilute alkali. Fresh solutions were prepared daily by dissolving pre-weighed aliquots of $6-\mathrm{MP}$ in $1.0 \mathrm{~N}$ $\mathrm{NaOH}$ ( $1 \mathrm{ml}$. of alkali per $100 \mathrm{mg}$. of 6-MP) ; the resulting solution was diluted to the desired concentration with normal saline. All injections of the drug were given intramuscularly.

TABLE I

Effect of 6-mercaptopurine on the primary immune response*

\begin{tabular}{|c|c|c|c|c|c|c|c|c|c|c|c|}
\hline \multirow[b]{2}{*}{ No. } & \multicolumn{11}{|c|}{ Day after antigen injection } \\
\hline & 1 & 3 & 5 & 7 & 8 & 9 & 10 & 12 & 14 & 15 & 16 \\
\hline \multicolumn{12}{|c|}{ Controls } \\
\hline $\begin{array}{r}1 \\
2 \\
3 \\
4 \\
5 \\
6 \\
35 \\
36 \\
37 \\
38 \\
39 \\
\text { Avg. }\end{array}$ & $\begin{array}{l}35.6 \\
34.2 \\
31.0 \\
33.7 \\
33.2 \\
31.4 \\
32.5 \\
38.7 \\
36.9 \\
42.0 \\
41.1 \\
39.0\end{array}$ & $\begin{array}{l}21.2 \\
22.1 \\
21.4 \\
23.2 \\
24.3 \\
19.5 \\
17.3 \\
22.8 \\
26.9 \\
26.8 \\
25.5 \\
25.1\end{array}$ & $\begin{array}{r}16.1 \\
14.2 \\
11.3 \\
14.0 \\
14.1 \\
9.5 \\
12.7 \\
14.1 \\
17.1 \\
15.5 \\
15.1 \\
15.4\end{array}$ & $\begin{array}{r}5.0 \\
7.2 \\
6.3 \\
6.4 \\
8.6 \\
6.1 \\
8.3 \\
10.7 \\
13.8 \\
13.4 \\
8.7 \\
9.5\end{array}$ & $\begin{array}{l}2.1 \\
3.4 \\
2.7 \\
5.4 \\
3.4 \\
3.2 \\
3.9 \\
6.6 \\
8.0 \\
6.9 \\
5.1 \\
5.1\end{array}$ & $\begin{array}{l}0.3 \\
0.4 \\
0.6 \\
1.6 \\
0.6 \\
0.3 \\
1.0 \\
1.2 \\
1.8 \\
0.9 \\
0.8 \\
1.0\end{array}$ & $\begin{array}{l}0.0 \\
0.0 \\
0.0 \\
0.0 \\
0.0 \\
0.0 \\
0.0 \\
0.0 \\
0.0 \\
0.0 \\
0.0 \\
0.0\end{array}$ & & & & \\
\hline \multicolumn{12}{|c|}{$1 \mathrm{mg} \cdot / \mathrm{Kg} \cdot / \mathrm{day}$} \\
\hline $\begin{array}{r}66 \\
67 \\
68 \\
69 \\
70 \\
\text { Avg. }\end{array}$ & $\begin{array}{l}37.0 \\
40.3 \\
41.1 \\
35.5 \\
46.0 \\
40.0\end{array}$ & & & $\begin{array}{r}13.1 \\
15.0 \\
15.5 \\
9.7 \\
15.6 \\
13.8\end{array}$ & $\begin{array}{r}10.2 \\
10.5 \\
11.4 \\
6.1 \\
11.7 \\
10.0\end{array}$ & $\begin{array}{l}8.1 \\
7.4 \\
8.4 \\
4.1 \\
8.8 \\
7.4\end{array}$ & $\begin{array}{l}6.4 \\
5.0 \\
5.1 \\
3.7 \\
5.7 \\
5.2\end{array}$ & $\begin{array}{l}4.5 \\
0.8 \\
0.7 \\
0.9 \\
1.9 \\
1.8\end{array}$ & $\begin{array}{l}2.4 \\
0.0 \\
0.0 \\
0.0 \\
0.0 \\
0.5\end{array}$ & & \\
\hline \multicolumn{12}{|c|}{$2 \mathrm{mg} \cdot / \mathrm{Kg} \cdot / \mathrm{day}$} \\
\hline $\begin{array}{r}55 \\
56 \\
57 \\
58 \\
59 \\
\text { Avg. }\end{array}$ & $\begin{array}{l}31.6 \\
44.3 \\
49.5 \\
43.4 \\
45.9 \\
42.9\end{array}$ & $\begin{array}{l}23.2 \\
26.7 \\
\\
28.4 \\
35.7 \\
28.5\end{array}$ & $\begin{array}{l}16.7 \\
10.1 \\
19.8 \\
15.9 \\
19.7 \\
16.4\end{array}$ & & $\begin{array}{r}10.8 \\
9.3 \\
11.5 \\
8.3 \\
8.6 \\
9.7\end{array}$ & $\begin{array}{l}8.3 \\
7.2 \\
8.6 \\
9.8 \\
7.4 \\
8.3\end{array}$ & $\begin{array}{l}7.1 \\
5.2 \\
8.4 \\
4.1 \\
6.2 \\
6.2\end{array}$ & $\begin{array}{l}4.5 \\
3.2 \\
4.7 \\
5.3 \\
3.6 \\
4.3\end{array}$ & $\begin{array}{l}0.2 \\
0.9 \\
0.9 \\
0.8 \\
0.6 \\
0.6\end{array}$ & $\begin{array}{l}0.0 \\
0.0 \\
0.0 \\
0.0 \\
0.0 \\
0.0\end{array}$ & \\
\hline \multicolumn{12}{|c|}{$3 \mathrm{mg} \cdot / \mathrm{Kg} \cdot / \mathrm{day}$} \\
\hline $\begin{array}{r}7 \\
8 \\
9 \\
10 \\
22 \\
\text { Avg. }\end{array}$ & $\begin{array}{l}34.7 \\
32.1 \\
33.6 \\
34.0 \\
34.1 \\
33.7\end{array}$ & $\begin{array}{l}21.5 \\
23.5 \\
26.0 \\
24.1 \\
19.7 \\
21.2\end{array}$ & $\begin{array}{l}12.6 \\
16.8 \\
18.5 \\
15.0 \\
15.5 \\
15.7\end{array}$ & $\begin{array}{r}8.7 \\
12.0 \\
16.0 \\
12.7 \\
10.8 \\
12.0\end{array}$ & $\begin{array}{r}7.8 \\
10.6 \\
13.8 \\
11.6 \\
8.3 \\
10.4\end{array}$ & $\begin{array}{r}6.5 \\
9.7 \\
13.6 \\
9.8 \\
7.2 \\
9.4\end{array}$ & & $\begin{array}{r}4.0 \\
7.7 \\
12.6 \\
8.0 \\
6.3 \\
7.7\end{array}$ & $\begin{array}{l}2.1 \\
4.2 \\
5.8 \\
3.7 \\
3.6 \\
3.9\end{array}$ & $\begin{array}{l}0.2 \\
0.1 \\
0.8 \\
0.7 \\
0.4 \\
0.4\end{array}$ & $\begin{array}{l}0.0 \\
0.0 \\
0.0 \\
0.0 \\
0.0 \\
0.0\end{array}$ \\
\hline \multicolumn{12}{|c|}{$6 \mathrm{mg} \cdot / \mathrm{Kg} \cdot / \mathrm{day}$} \\
\hline $\begin{array}{r}152 \\
153 \\
154 \\
155 \\
156 \\
157 \\
161 \\
162 \\
163 \\
164 \\
165 \\
166 \\
\text { Avg. }\end{array}$ & $\begin{array}{l}29.3 \\
36.2 \\
33.9 \\
29.0 \\
40.8 \\
26.1 \\
24.2 \\
31.5 \\
30.4 \\
37.3 \\
29.2 \\
30.7 \\
31.6\end{array}$ & & & $\begin{array}{r}10.1 \\
8.2 \\
7.1 \\
3.7 \\
8.4 \\
8.2 \\
11.1 \\
14.1 \\
16.0 \\
15.3 \\
13.5 \\
14.2 \\
10.8\end{array}$ & & & $\begin{array}{r}6.4 \\
5.5 \\
4.8 \\
4.0 \\
5.2 \\
5.5 \\
5.5 \\
8.2 \\
8.6 \\
8.0 \\
6.6 \\
12.0 \\
6.7\end{array}$ & $\begin{array}{l}5.4 \\
5.1 \\
3.8 \\
2.7 \\
\\
4.7\end{array}$ & $\begin{array}{l}2.7 \\
2.1 \\
1.6 \\
1.1 \\
\\
2.0 \\
3.4 \\
5.5 \\
5.8 \\
6.0 \\
1.7 \\
7.9 \\
3.4\end{array}$ & & $\begin{array}{l}2.4 \\
3.5 \\
2.6 \\
3.2 \\
0.5 \\
4.3 \\
1.9\end{array}$ \\
\hline
\end{tabular}

* The value for each animal represents percentage of initial radioactivity. 
TABLE II

Percentage of globulin-bound antigen appearing during the primary response

\begin{tabular}{|c|c|c|c|c|c|c|c|c|c|c|}
\hline \multirow[b]{2}{*}{ No. } & \multicolumn{10}{|c|}{ Day after antigen injection } \\
\hline & 1 & 3 & 5 & 7 & 8 & 9 & 10 & 12 & 14 & $\overline{16}$ \\
\hline \multicolumn{11}{|c|}{ Controls } \\
\hline $\begin{array}{r}1 \\
2 \\
3 \\
4 \\
5 \\
6 \\
35 \\
36 \\
37 \\
38 \\
39 \\
\text { Avg. }\end{array}$ & $\begin{array}{l}2.1 \\
1.2 \\
1.4 \\
1.7 \\
0.8 \\
3.6 \\
1.2 \\
4.1 \\
2.5 \\
0.6 \\
1.4 \\
1.9\end{array}$ & $\begin{array}{l}1.9 \\
3.2 \\
2.1 \\
1.6 \\
1.9 \\
1.4 \\
6.1 \\
\\
2.6 \\
3.8 \\
2.7\end{array}$ & $\begin{array}{l}1.7 \\
2.8 \\
2.1 \\
3.7 \\
2.3 \\
0.7 \\
0.8 \\
2.3 \\
2.8 \\
1.1 \\
2.0\end{array}$ & $\begin{array}{r}2.3 \\
1.6 \\
1.6 \\
4.3 \\
0.7 \\
1.2 \\
1.4 \\
11.0 \\
17.0 \\
6.3 \\
0.7 \\
4.8\end{array}$ & $\begin{array}{l}18.3 \\
54.0 \\
41.2 \\
36.8 \\
58.3 \\
75.3 \\
48.3 \\
62.3 \\
51.4 \\
46.9 \\
79.8 \\
45.9\end{array}$ & $\begin{array}{r}88.3 \\
93.2 \\
78.6 \\
84.3 \\
98.0 \\
67.8 \\
87.2 \\
100.0 \\
93.0 \\
87.6 \\
96.3 \\
97.4\end{array}$ & $\begin{array}{l}0.0 \\
0.0 \\
0.0 \\
0.0 \\
0.0 \\
0.0 \\
0.0 \\
0.0 \\
0.0 \\
0.0 \\
0.0 \\
0.0\end{array}$ & & & \\
\hline \multicolumn{11}{|c|}{ 6-MP, $6 \mathrm{mg} . / \mathrm{Kg} . / \mathrm{day}$} \\
\hline $\begin{array}{r}152 \\
153 \\
154 \\
155 \\
156 \\
157 \\
161 \\
162 \\
163 \\
164 \\
165 \\
166 \\
\text { Avg. }\end{array}$ & $\begin{array}{l}1.6 \\
3.2 \\
0.9 \\
1.7 \\
1.5 \\
1.3 \\
1.2 \\
3.4 \\
1.4 \\
0.7 \\
1.1 \\
0.9 \\
1.6\end{array}$ & & . & $\begin{array}{l}4.6 \\
1.4 \\
1.9 \\
4.1 \\
1.3 \\
7.5 \\
3.5 \\
2.4 \\
3.5 \\
2.3 \\
4.3 \\
3.2 \\
3.3\end{array}$ & & & $\begin{array}{l}2.2 \\
1.6 \\
0.9 \\
3.4 \\
3.2 \\
1.4 \\
2.1 \\
3.2 \\
0.8 \\
0.7 \\
1.9 \\
1.1 \\
1.8\end{array}$ & $\begin{array}{l}0.3 \\
2.3 \\
2.3 \\
3.1 \\
2.4 \\
1.1 \\
1.0 \\
1.6 \\
1.2 \\
1.6 \\
2.0 \\
1.0 \\
1.7\end{array}$ & $\begin{array}{l}1.6 \\
2.4 \\
1.4 \\
1.4 \\
1.5 \\
0.8 \\
2.4 \\
7.1 \\
3.4 \\
1.2 \\
1.0 \\
5.4 \\
2.5\end{array}$ & $\begin{array}{l}1.5 \\
1.7 \\
1.9 \\
2.9 \\
3.2 \\
1.7 \\
1.8 \\
1.0 \\
1.9 \\
3.1 \\
0.9 \\
3.2 \\
2.1\end{array}$ \\
\hline
\end{tabular}

Estimation of antibody production. Two methods were used: 1) After the radioactivity of the serum samples had been determined, sufficient saturated ammonium sulfate was added to produce a final concentration of 50 per cent ammonium sulfate. The precipitated globulins were washed three to four times in half-saturated ammonium sulfate, or until the supernatant contained no radioactivity. After discarding the supernatant, the radioactivity of the precipitate was measured as described above. The radioactivity of the washed globulin precipitate indicated the relative concentration of circulating antigen-antibody complexes since only the human albumin firmly bound to rabbit globulin precipitated in the half-saturated ammonium sulfate. 2) "Free" serum antibody was measured at various intervals by the tannic acid hemagglutination method of Stavitsky (9), with one minor modification, namely, normal saline was substituted for buffered $(\mathrm{pH}$ 7.4) saline, since in our hands this change produced sharper agglutination patterns. Results of these tests were expressed as the $\log _{2}$ of the highest dilution of serum showing a $1+$ pattern.

Immunization, dosage and bleeding schedules. 1) Primary response: Thirty-eight animals, 11 in the control group and 27 in the experimental groups, were used. Each animal was given one intravenous injection of 10 to 15 $\mu \mathrm{c}$. of HSA-I mixed with $20 \mathrm{mg}$. of "carrier" HSA. The experimental groups were given 6-MP in the following dosage schedules: $1 \mathrm{mg}$. per $\mathrm{Kg}$. per day, $2 \mathrm{mg}$. per $\mathrm{Kg}$. per day, $3 \mathrm{mg}$. per $\mathrm{Kg}$. per day and $6 \mathrm{mg}$. per
Kg. per day. Administration of the drug was begun on the first day of antigen injection (Day "O") and was continued for 13 days. Blood was obtained from the marginal ear veins. An initial bleeding was obtained 15 minutes after the injection of the antigen and the counts per minute of this sample were taken as 100 per cent radioactivity. Bleedings were made either daily or every second or third day, as indicated in the Results.

2) Secondary response. Eighteen animals, eight in the control group and 10 in the drug treated groups, were used. Each animal was given a single intravenous injection of $100 \mathrm{mg}$. of HSA. Six to 12 weeks later a second injection of 10 to $15 \mu \mathrm{c}$. of HSA-I together with $20 \mathrm{mg}$. of "carrier" protein were administered intravenously. The experimental groups were given 6-MP in the following doses: $3 \mathrm{mg}$. per $\mathrm{Kg}$. per day for five days and $6 \mathrm{mg}$. per Kg. per day for eight days, beginning with the second injection of antigen. Blood was obtained as for the primary response.

\section{RESULTS}

\section{The primary response}

The results of these experiments are illustrated in Figures 1,2 and 3 and the data for each rabbit are listed in Tables I, II and III. The disappearance of HSA-I from the serums of the untreated animals occurred in three distinct phases, 
TABLE III

Production of humoral antibody during the primary response*

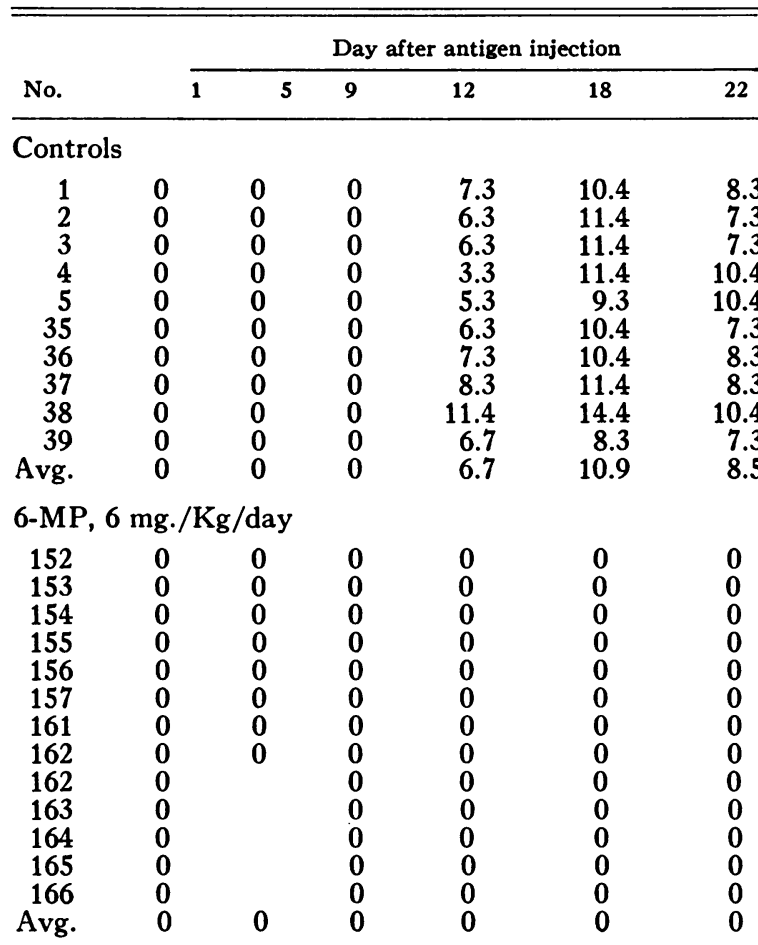

* Titers for tannic acid hemagglutination tests; values are expressed as the $\log _{2}$ of the highest dilution giving a $1+$ pattern.

corresponding closely to the results obtained by Talmage and associates ( 7 ), and by Dixon (10). During the first 24 hours about two-thirds of the initial radioactivity disappeared from the serum. The remaining one-third then showed a logarithmic decay curve similar to that seen with other circulating proteins. However, on the seventh day after antigen injection an accelerated disappearance phase began, and within three days all traces of radioactivity were gone from the circulation. Coincident with this accelerated disappearance of antigen ("immune disappearance phase") there was a sharp rise in the percentage of HSA-I bound to globulin, indicating the appearance of circulating antigen-antibody complexes. Nine days after antigen injection, practically all of the detectable isotope was in the globulin fraction. Twelve days after the administration of the antigen the tannic acid hemagglutination tests were positive, indicating the presence of "free" humoral antibody. Antibody titers reached their peaks about 18 days after the injection of antigen and thereafter began to decline.

All groups of animals treated with 6-MP behaved quantitatively differently from the control group, except the group treated with $6 \mathrm{mg}$. per $\mathrm{Kg}$. per day, which differed both quantitatively and qualitatively from the untreated animals. This latter group will be discussed separately. The immune disappearance phase developed in each of the other groups of treated animals, but the time of onset was delayed in proportion to the dose of 6-MP administered. Thus, in the group given $1 \mathrm{mg}$. per $\mathrm{Kg}$. per day the accelerated portion of the curve began on the ninth day; those animals treated with $2 \mathrm{mg}$. per $\mathrm{Kg}$. per day developed this phase on the twelfth day; while the group in which $3 \mathrm{mg}$. per $\mathrm{Kg}$. per day was given responded on the fourteenth day. This relationship between dose and suppression of the immune response was arbitrarily expressed as a percentage

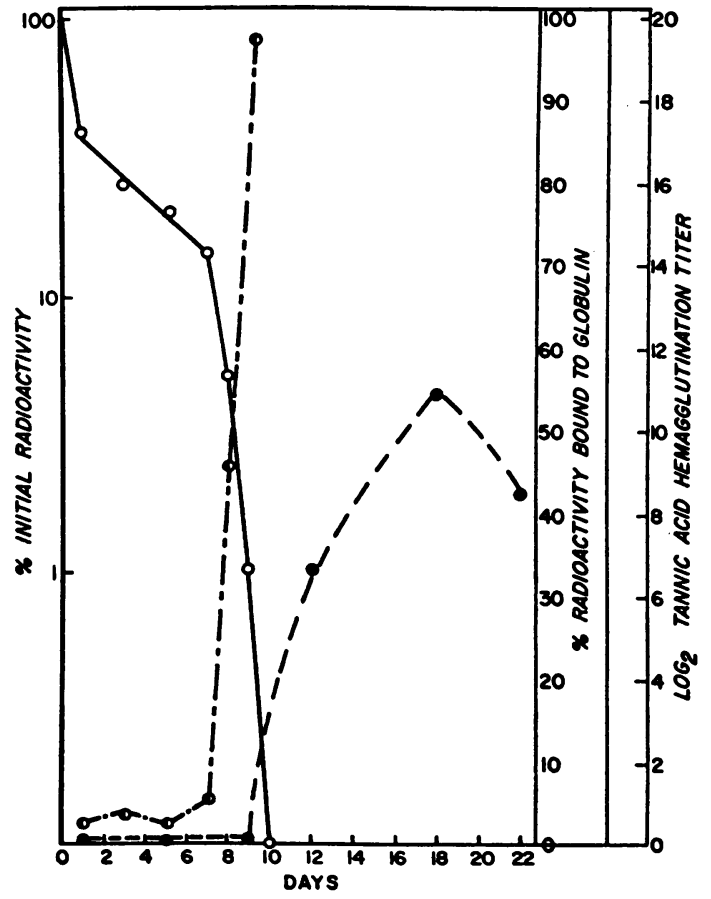

Fig. 1. Antigen Disappearance and Antibody Appearance Following the Intravenous AdministraTION OF HSA-I to Control Animals

$\mathrm{O}-\mathrm{O}-\mathrm{O}$, per cent initial radioactivity remaining in serum; $\mathrm{O}--\mathrm{O}---\mathrm{O}$, per cent radioactivity bound to globulin; $\mathrm{O}-\mathrm{O}-\mathrm{O}$, tannic acid hemagglutination titer. Each point represents the average value for the group. 


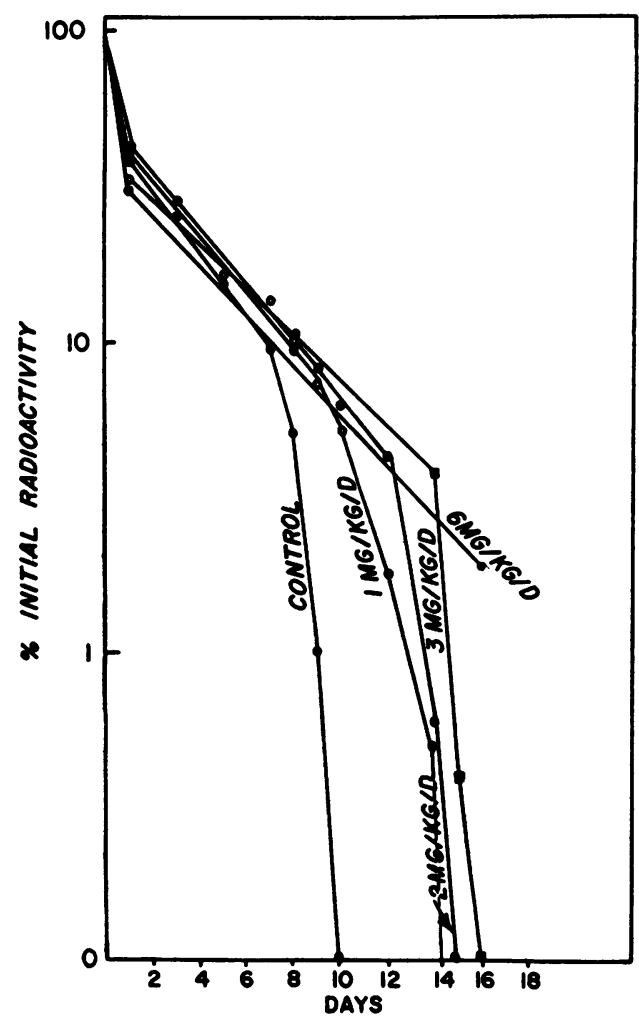

Fig. 2. Antigen Disappearance in Control and 6-MP Treated Animals

Each point represents the average value for the group.

of "immunological efficiency" by assuming the untreated animals to be 100 per cent efficient; the efficiencies of the treated groups were calculated according to the formula :

Per cent immunological efficiency

$$
=\frac{\text { induction period of controls }}{\text { induction period of treated group }} \times 100 \text {. }
$$

This relationship is illustrated in Figure 4 . It can be seen that a linear relationship exists between the dose of 6-MP and the arbitrary "immunological efficiency."

The rabbits treated with 6-MP in a dose of 6 mg. per Kg. per day did not develop the third phase of antigen disappearance. After initial equilibration, the antigen decayed logarithmically until the sixteenth day after its injection; further determinations of serum radioactivity were not done because the very small amount of isotope remaining precluded accurate count. At no time did antigen-antibody complexes appear. $\mathrm{Hu}$ moral antibodies were not detected during the 25 days of the study. Further evidence that antibody production was completely blocked was obtained by reinjecting this group with a second dose of HSA-I. These results, which will be reported in detail elsewhere (11), indicate that antibody was absent from the blood of these animals at the time of the second injection of antigen.

\section{The secondary response.}

The results of these experiments are illustrated in Figures 5 and 6 and the data for each rabbit are listed in Tables IV, V and VI. Radiolabeled antigen disappeared from the circulation of the control group in the three distinct phases previously described. The onset of the immune disappearance phase, however, occurred much earlier - on the third day after antigen injection, and by the fifth day no circulating antigen was detectable. On the fourth day most of the circulating antigen was bound to globulin as antigen-antibody complexes. Five days after the injection of antigen "free" humoral antibody was detected by the tannic acid hemagglutination method; titers

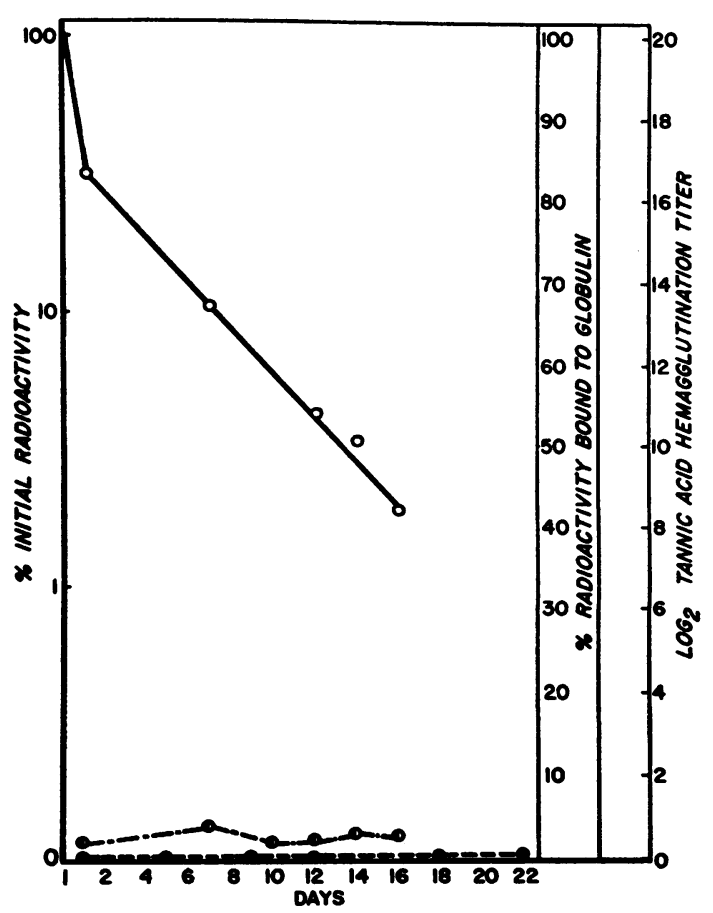

Fig. 3. Antigen Disappearance and Lack of Antibody Formation in Animals Treated with 6-MP (6 MG. PER KG. PER DAy) FOR 13 DAys

Each point represents the average value for the group. 


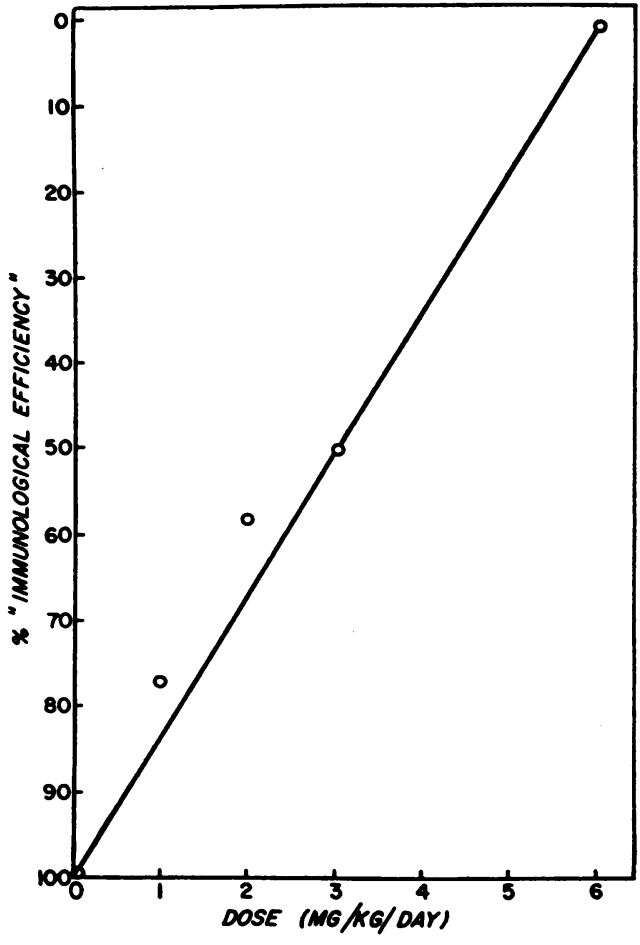

Fig. 4. Relationship Between Dose of 6-MP and DePRESSION OF "IMMUNOLOGICAL EFFICIENCY"

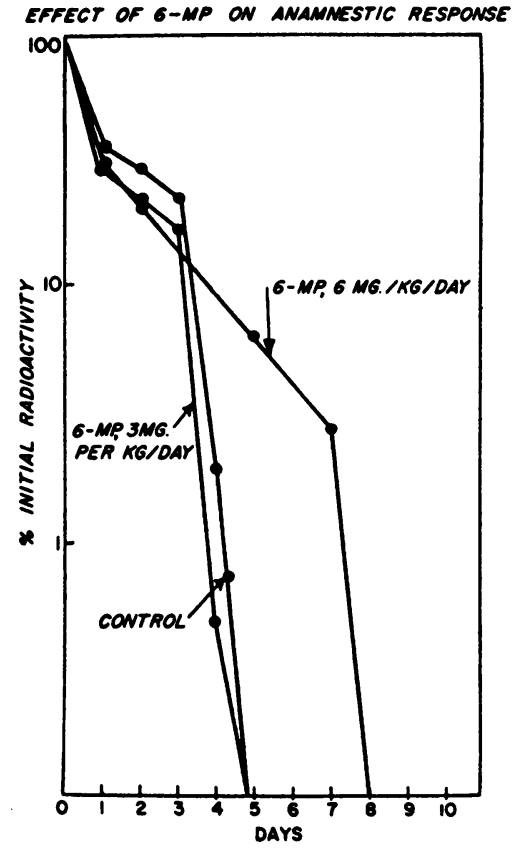

Fig. 5. Antigen Disappearance During the SecondARY IMMUNE RESPONSE

Each point represents the average value for the group.

TABLE IV

Effect of 6-mercaptopurine on the secondary immune response*

\begin{tabular}{|c|c|c|c|c|c|c|c|c|c|}
\hline \multirow[b]{2}{*}{ No. } & \multicolumn{9}{|c|}{ Day after antigen injection } \\
\hline & 1 & 2 & 3 & 4 & 5 & 6 & 7 & 8 & 9 \\
\hline \multicolumn{10}{|c|}{ Controls } \\
\hline $\begin{array}{r}1 \\
2 \\
3 \\
5 \\
55 \\
57 \\
58 \\
59 \\
\text { Avg. }\end{array}$ & $\begin{array}{l}44.4 \\
39.0 \\
36.6 \\
39.9 \\
37.4 \\
38.6 \\
40.0 \\
49.2 \\
40.6\end{array}$ & $\begin{array}{l}32.8 \\
29.9 \\
30.6 \\
36.0\end{array}$ & $\begin{array}{l}17.2 \\
16.3 \\
15.4 \\
18.2 \\
27.5 \\
28.5 \\
36.6 \\
34.4 \\
24.2\end{array}$ & $\begin{array}{l}2.1 \\
0.7 \\
4.5 \\
0.9 \\
2.8 \\
1.7 \\
1.8 \\
0.1 \\
1.8\end{array}$ & $\begin{array}{l}1.3 \\
0.2 \\
0.7 \\
0.1 \\
0.1 \\
0.0 \\
0.1 \\
0.0 \\
0.3\end{array}$ & $\begin{array}{l}0.0 \\
0.0 \\
0.0 \\
0.0 \\
0.0 \\
0.0 \\
0.0 \\
0.0 \\
0.0\end{array}$ & & & \\
\hline \multicolumn{10}{|c|}{ 6-MP, $3 \mathrm{mg} \cdot / \mathrm{Kg} \cdot /$ day } \\
\hline $\begin{array}{r}29 \\
30 \\
31 \\
32 \\
\text { Avg. }\end{array}$ & $\begin{array}{l}40.5 \\
35.3 \\
29.1 \\
30.5 \\
33.9\end{array}$ & $\begin{array}{l}32.8 \\
20.6 \\
15.5 \\
20.0 \\
22.3\end{array}$ & $\begin{array}{l}18.3 \\
17.6 \\
10.4 \\
11.3 \\
14.4\end{array}$ & $\begin{array}{l}0.9 \\
1.8 \\
0.1 \\
0.7 \\
0.9\end{array}$ & $\begin{array}{l}0.2 \\
0.3 \\
0.1 \\
0.0 \\
0.2\end{array}$ & $\begin{array}{l}0.0 \\
0.0 \\
0.0 \\
0.0 \\
0.0\end{array}$ & & & \\
\hline \multicolumn{10}{|c|}{ 6-MP, $6 \mathrm{mg} . / \mathrm{Kg} . /$ day } \\
\hline $\begin{array}{r}116 \\
117 \\
118 \\
119 \\
120 \\
125 \\
\text { Avg. }\end{array}$ & $\begin{array}{l}30.3 \\
33.2 \\
31.9 \\
34.3 \\
31.7 \\
33.3 \\
32.5\end{array}$ & $\begin{array}{l}25.9 \\
22.3 \\
25.8 \\
22.3 \\
21.5 \\
24.2 \\
23.7\end{array}$ & $\begin{array}{l}18.8 \\
21.0 \\
19.2 \\
17.2 \\
14.3 \\
20.1 \\
18.4\end{array}$ & $\begin{array}{r}13.6 \\
16.0 \\
5.5 \\
7.9 \\
8.1 \\
17.6 \\
11.5\end{array}$ & $\begin{array}{r}9.0 \\
10.2 \\
2.3 \\
2.3 \\
5.4 \\
12.0 \\
6.9\end{array}$ & & $\begin{array}{l}3.8 \\
3.4 \\
1.2 \\
1.1 \\
2.2 \\
5.6 \\
2.9\end{array}$ & $\begin{array}{l}0.1 \\
0.1 \\
0.1 \\
0.1 \\
\\
0.4 \\
0.1\end{array}$ & $\begin{array}{l}0.0 \\
0.0 \\
0.0 \\
0.0 \\
0.0 \\
0.0 \\
0.0\end{array}$ \\
\hline
\end{tabular}

* The value for each animal represents the percentage of initial radioactivity. 


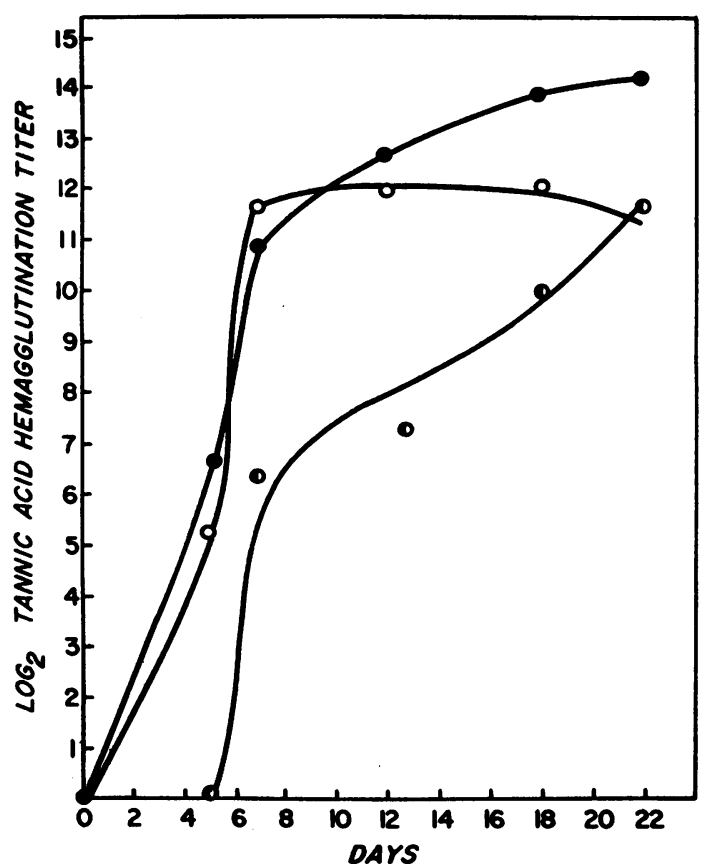

Fig. 6. Production of Antibody During the SecondARY Response

$\mathrm{O}-\mathrm{O}-\mathrm{O}$, control group; $-\bullet-\bullet, 6-\mathrm{MP}, 3 \mathrm{mg}$. per Kg. per day; -- - 6-MP, $6 \mathrm{mg}$. per Kg. per day.

TABLE V

Percentage of globulin-bound antigen appearing during the secondary response

\begin{tabular}{|c|c|c|c|c|c|c|}
\hline \multirow[b]{2}{*}{ No. } & \multicolumn{6}{|c|}{ Day after antigen injection } \\
\hline & 1 & 3 & 4 & 7 & 8 & 9 \\
\hline \multicolumn{7}{|c|}{ Control } \\
\hline $\begin{array}{r}1 \\
2 \\
3 \\
5 \\
55 \\
57 \\
58 \\
59 \\
\text { Avg. }\end{array}$ & $\begin{array}{l}1.2 \\
1.6 \\
3.2 \\
4.8 \\
1.7 \\
6.7 \\
2.3 \\
1.6 \\
2.1\end{array}$ & $\begin{array}{l}2.1 \\
1.9 \\
2.3 \\
3.7 \\
2.3 \\
4.1 \\
2.6 \\
3.8 \\
2.9\end{array}$ & $\begin{array}{c}88.2 \\
93.1 \\
87.2 \\
67.8 \\
93.0 \\
0 \\
84.1 \\
0 \\
64.0\end{array}$ & $\begin{array}{l}0 \\
0 \\
0 \\
0 \\
0 \\
0 \\
0 \\
0 \\
0\end{array}$ & & \\
\hline \multicolumn{7}{|c|}{ 6-MP, $3 \mathrm{mg} . / \mathrm{Kg} . /$ day } \\
\hline $\begin{array}{r}29 \\
30 \\
31 \\
32 \\
\text { Avg. }\end{array}$ & $\begin{array}{l}3.1 \\
1.6 \\
0.7 \\
1.4 \\
1.7\end{array}$ & $\begin{array}{l}1.4 \\
2.8 \\
3.1 \\
0.5 \\
1.9\end{array}$ & $\begin{array}{l}92.1 \\
91.7 \\
87.3 \\
94.6 \\
91.4\end{array}$ & $\begin{array}{l}0 \\
0 \\
0 \\
0 \\
0\end{array}$ & & \\
\hline \multicolumn{7}{|c|}{$6 \mathrm{mg} \cdot / \mathrm{Kg} \cdot /$ day } \\
\hline $\begin{array}{r}116 \\
117 \\
118 \\
119 \\
120 \\
125 \\
\text { Avg. }\end{array}$ & $\begin{array}{l}1.2 \\
2.1 \\
4.1 \\
3.6 \\
1.7 \\
0.9 \\
2.1\end{array}$ & $\begin{array}{l}1.9 \\
3.3 \\
1.6 \\
1.7 \\
\\
1.9 \\
1.9\end{array}$ & $\begin{array}{l}2.1 \\
4.3 \\
0.9 \\
1.6 \\
2.8 \\
1.1 \\
2.2\end{array}$ & $\begin{array}{l}22.1 \\
40.3 \\
56.2 \\
39.7 \\
44.3 \\
63.1 \\
45.9\end{array}$ & $\begin{array}{l}90.1 \\
95.7 \\
88.3 \\
67.8 \\
92.1 \\
91.1 \\
87.3\end{array}$ & $\begin{array}{l}0 \\
0 \\
0 \\
0 \\
0 \\
0 \\
0\end{array}$ \\
\hline
\end{tabular}

TABLE VI

Production of humoral antibody during the secondary immune response*

\begin{tabular}{|c|c|c|c|c|c|c|}
\hline \multirow[b]{2}{*}{ No. } & \multicolumn{6}{|c|}{ Day after antigen injection } \\
\hline & 1 & 5 & 7 & 12 & 18 & 22 \\
\hline 1 & 0 & 4.3 & 9.3 & 7.3 & 6.3 & 7.3 \\
\hline 2 & 0 & 5.3 & 10.4 & 14.4 & 14.4 & 14.4 \\
\hline 3 & 0 & 4.3 & 10.4 & 13.4 & 12.4 & 13.4 \\
\hline 5 & 0 & 3.3 & 14.4 & 14.4 & 10.4 & 9.3 \\
\hline 35 & 0 & 7.3 & 14.4 & 13.4 & 13.4 & 8.3 \\
\hline 36 & 0 & 8.3 & 14.4 & 14.4 & 12.4 & 12.4 \\
\hline 37 & 0 & 5.3 & 10.3 & 7.3 & 12.4 & 11. \\
\hline 38 & 0 & 3.3 & 11.4 & 12.4 & 12.4 & \\
\hline 39 & 0 & 6.3 & 10.3 & 11.4 & 14.4 & 14.4 \\
\hline Avg. & 0 & 5.3 & 11.7 & 12.0 & 12.1 & 11.7 \\
\hline \multicolumn{7}{|c|}{$\begin{array}{l}\text { Controls } \\
3 \mathrm{mg} . / \mathrm{Kg} . / \text { day }\end{array}$} \\
\hline 29 & 0 & 4.3 & 8.3 & 14.4 & 14.4 & 13.4 \\
\hline 30 & 0 & 6.3 & 9.3 & 13.4 & 12.4 & 14. \\
\hline 31 & 0 & 7.3 & 11.4 & 10.4 & 14.4 & 14. \\
\hline 32 & 0 & 8.3 & 14.4 & 12.4 & 14.4 & 14.4 \\
\hline Avg. & 0 & 6.6 & 10.9 & 12.7 & 13.9 & 14 \\
\hline \multicolumn{7}{|c|}{ 6-MP, $6 \mathrm{mg} . / \mathrm{Kg} . /$ day } \\
\hline 116 & 0 & 0 & 4.3 & 4.3 & 9.3 & 9.3 \\
\hline 117 & 0 & 0 & 0 & 0 & 8.3 & \\
\hline 118 & 0 & 0 & 14.4 & 14.4 & 14.4 & 14.4 \\
\hline 119 & 0 & 0 & 12.4 & 14.4 & 14.4 & 14. \\
\hline 120 & 0 & 0 & 7.3 & & & \\
\hline 125 & 0 & 0 & 0 & 3.3 & 3.3 & 8.3 \\
\hline Avg. & 0 & 0 & 6.4 & 7.3 & 10.0 & 11. \\
\hline
\end{tabular}

* Titers for tannic acid hemagglutination tests; values are expressed as the $\log _{2}$ of the highest dilution giving a $1+$ pattern.

quickly rose and by the twelfth day they were at their peak.

6-MP, when given in a dose of $3 \mathrm{mg}$. per $\mathrm{Kg}$. per day, had no effect on the secondary response. However, when twice that dose was given the onset of the immune disappearance phase occurred in the seventh day rather than on the third day. "Free" antibody appeared on the ninth day and the tannic acid hemagglutination titers rose thereafter to a peak on the twenty-second day after antigen injection. Although the animals of this group eventually attained antibody titers equal to those of the control group, the rate of increase was more gradual than in the untreated animals.

\section{DISCUSSION}

Antibody formation has been suppressed by a number of agents, including X-radiation (12), nitrogen mustard (13), thorium dioxide (14), cortisone (15), vitamin deficiencies (16), vitamin analogs (17), amino acid analogs (18), and purine antagonists $(6,19-21)$. Some of these, 


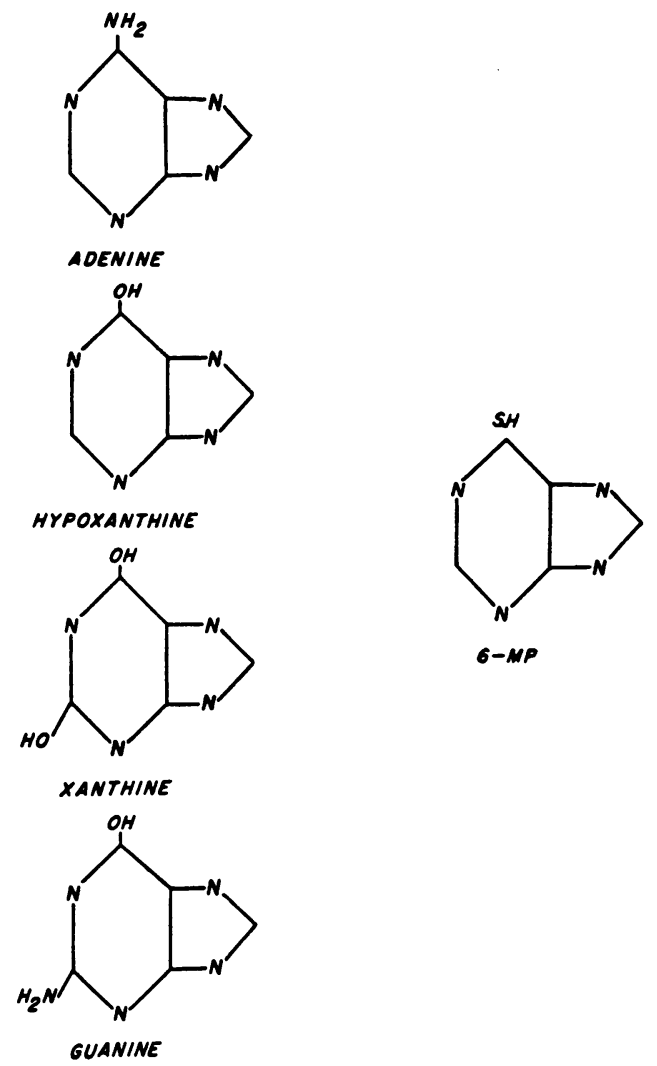

Fig. 7. Structural Formulas of 6-MP and Related Purines

such as X-radiation and nitrogen mustard, appear to exert their effects by direct destruction of antibody forming tissue; others, such as thorium dioxide, may act by inhibiting the function of the reticuloendothelial system. Metabolic antagonists of vitamins, amino acids and purines have striking effects on antibody production, but their mechanisms of action are poorly understood.

Although the effects of 6-MP (Figure 7) on immune responses are clearcut, its exact mode of action at the "biochemical level" is not well understood. There is much evidence to support the view that 6-MP acts as a nucleic acid antagonist, but the precise details of its action are ill defined. Its role in purine metabolism has been extensively investigated and it has been shown that 6-MP inhibits the incorporation of $\mathrm{P}^{32}$ into the nucleic acids of mouse tumors (22); not only is the de novo synthesis of nucleic acids by Sarcoma 180 cells suppressed by this agent (23), but radiolabeled 6-MP is probably synthesized into the nucleic acid molecules of certain cells (24).
Other studies have demonstrated that the incorporation of hypoxanthine into nucleic acids of viruses is blocked by this agent (25). 6-MP probably acts as a nonspecific purine antagonist, since its inhibitory action on bacterial growth can be reversed by any of the natural purines (26). Work with 6-MP resistant mutants of $L$. case $i$ suggested that 6-MP interferes with the conversion of adenine to guanine via hypoxanthine (27); this conclusion was later supported by experiments done with $\mathrm{C}^{14}$ labeled adenine which demonstrated that the 6-MP resistant mutant lacks a pathway for converting hypoxanthine to nucleic acid purines (28). Skipper came to similar conclusions concerning this action of 6-MP from his studies of the intestinal tissues of mice treated with this compound (23). 6-MP may also act on nucleic acid metabolism by interfering with normal purine interconversion mechanisms (29) or by competing with enzymes responsible for the conjugation of purine bases with ribose sugars, thereby forming ribosides and ribotides (30).

The widespread occurrence of purine moieties in nature has led to the investigation of the effect of 6-MP on systems other than nucleic acid metabolism. Thus, it has been found that the in vitro antimitotic activity of 6-MP can be overcome by coenzyme $A$, an adenine containing derivative of pantothenic acid essential in lipid metabolism (31); the increase in tissue diphosphopyridine nucleotide (DPN) that usually appears after the injection of nicotinamide into mice is prevented by treatment of these animals with 6MP (32); amino acid (glutamate) incorporation into pea-seedling protein has been blocked with 6MP (33); diminished amounts of adenosine triphosphate (ATP) have been found in tumorbearing mice treated with this compound (34); and interference with hexokinase by 6-MP has been shown both in vivo and in vitro $(35,36)$. Whether the demonstrated effects of 6-MP on nucleic acid metabolism are the primary actions of this drug, or whether it acts through interference with other systems, such as ATP or hexokinase, and only secondarily induces biochemical lesions in nucleic acids, are speculative points. In any event, it is probable that the principle observable effect of 6-MP is on nucleic acid metabolism.

Certain conclusions can be drawn concerning the effect of 6-MP at the "immunological level." 
It is possible to effect a complete block of the primary response to a soluble protein antigen with this agent. The linear relationship between the dose of 6-MP and its effect on antibody production suggests that the action of the drug in this regard might be that of a first-order chemical reaction, rather than that of a direct cytotoxic effect, as is seen with $\mathrm{X}$-radiation or nitrogen mustard. If one assumes that the drug diffuses freely into all cells, and reaches approximately the same concentration in each antibody forming cell, then its action on antibody formation is probably not due to immediate death of antibody producing cells, since the dose-effect relationship is linear, rather than sigmoidal. This latter type of curve has been found by Makinodan and Gengozian (37) to express the effect of progressively increasing doses of $\mathrm{X}$-radiation on immune responses in mice. The amount of 6-MP which effectively prevents antibody production during the primary response is only partially effective in preventing the appearance of a secondary response. The rapid onset and more intense cellular activity of antibody forming tissues which characterize the anamnestic response may also be accompanied by different metabolic patterns, either quantitative or qualitative, with different susceptibilities to 6-MP. An alternate explanation may be that these differences are a reflection of a smaller amount of drug available per cell during this phase of the immune response.

That 6-MP acts on antibody formation by nonspecific inhibition of protein production seems unlikely in view of the observation that the serum protein patterns of hyperimmunized animals treated with this drug are no different than those of control hyperimmunized rabbits (38). Furthermore, it has been shown that 6-MP does not affect non-neoplastic anabolism in man; the materials excreted during tumor shrinkage caused by the drug are derived solely from tumor destruction (39). Other experiments (40) have demonstrated that 6-MP does not interfere with the in vivo uptake of cellular antigens by the reticuloendothelial system, and it can be concluded that the drug does not suppress ingress of antigen into antibody producing cells.

In summary, then, the effects of 6-MP on both the primary and secondary inmmune responses may best be explained by a direct chemical at- tack on antibody forming tissue, probably through interference with nucleic acid metabolism.

\section{SUMMARY}

1. The administration of 6-mercaptopurine (6$\mathrm{MP}$ ), a purine analog, to rabbits in a dosage of 6 $\mathrm{mg}$. per $\mathrm{Kg}$. per day resulted in complete blocking of the primary immune responses to a soluble protein antigen.

2. Below the dose of $6 \mathrm{mg}$. per $\mathrm{Kg}$. per day a linear relationship was found to exist between the effect on the primary response and the dose of drug.

3. That dose of 6-MP which completely blocked the appearance of the primary response was only partially effective in preventing the onset of the secondary response.

\section{ACKNOWLEDGMENTS}

The authors gratefully acknowledge the excellent technical assistance of Mrs. Frank Donovan (Janice Stack). $\mathrm{Mr}$. Walter Small gave invaluable advice concerning isotope detection and measurement. Mr. Louis Larsen of the Protein Foundation supplied us with generous quantities of human serum albumin, and Dr. Donald Searle, of Burroughs-Wellcome, Inc., provided us with the 6-mercaptopurine.

\section{REFERENCES}

1. Coons, A. H. The cytology of antibody formation. J. cell. comp. Physiol. 1958, 52, Suppl. 1, 55.

2. Good, R. A. Morphological basis of the immune response and hypersensitivity in Host-Parasite Relationships in Living Cells, A Symposium, H. M. Felton, Ed. Springfield, Ill., Charles C Thomas, 1957, p. 78.

3. Andreini, P., Drasher, M. L., and Mitchison, N. A. Studies on the immunological response to foreign tumor transplants in the mouse. II. Changes in the weight, and content of nucleic acids and protein, of host lymphoid tissues. J. exp. Med. 1955, 102, 199.

- 4. Harris, T. N., and Harris, S. Histochemical changes in lymphocytes during the production of antibodies in lymph nodes of rabbits. J. exp. Med. 1949, 90, 169.

5. Ehrich, W. E., Drabkin, D. L., and Forman, C. Nucleic acids and the production of antibody by plasma cells. J. exp. Med. 1949, 90, 157.

6. Schwartz, R., Stack, J., and Dameshek, W. Effect of 6-mercaptopurine on antibody production. Proc. Soc. exp. Biol. (N. Y.) 1958, 99, 164.

7. Talmage, D. W., Dixon, F. J., Bukantz, S. C., and Dammin, G. J. Antigen elimination from the blood 
as an early manifestation of the immune response. J. Immunol. 1951, 67, 243.

8. Farr, R. S. Measurement of antigen-combining capacity of antiserums, as determined by ammonium sulfate precipitation of $\mathrm{I}^{131}$ antigen after complex formation with antibody. Fed. Proc. 1956, 15, 586.

9. Stavitsky, A. B. Micromethods for the study of proteins and antibodies. J. Immunol. 1954, 72, 360.

10. Dixon, F. J. Characterization of the antibody response. J. cell. comp. Physiol. 1957, 50, Suppl. 1, 27.

11. Schwartz, R. S., Eisner, A., and Dameshek, W. Drug induced immunological tolerance. In preparation.

12. Taliaferro, W. H., and Tailiaferro, L. G. Effect of $\mathrm{X}$-rays on hemolysin formation following various immunization and irradiation procedures. $\mathrm{J}$. infect. Dis. 1954, 95, 117.

13. Green, D. M. The effects of nitrogen mustard (methyl bis ( $\beta$-chloroethyl) amine $\mathrm{HCl}$ ) on the immunological response of the rabbit. I. The effects of nitrogen mustard on the primary response to a bacterial antigen. Brit. J. exp. Path. 1958, 39, 192.

14. Hektoen, L., and Corper, H. J. The influence of thorium $\mathrm{X}$ on antibody formation. J. infect. Dis. 1920, 26, 330.

15. Kass, E. H., Kendrik, M. I., and Finland, M. Effects of corticosterone, hydrocortisone, and corticotropin on the production of antibodies in rabbits. J. exp. Med. 1955, 102, 767.

16. Axelrod, A. E. The role of nutritional factors in the antibody responses of the anamnestic process. Amer. J. clin. Nutr. 1958, 6, 119.

18. Wissler, R. W., Frazier, L. F., Soules, K. H., Barker, P., and Bristow, E. C., III. The acute

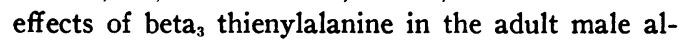
bino rat. A. M. A. Arch. Path. 1956, 62, 62.

19. Malmgren, R. A., Bennison, B. E., and McKinley, T. W., Jr. Reduced antibody titers in mice treated with carcinogenic and cancer chemotherapeutic agents. Proc. Soc. exp. Biol. (N. Y.) 1952, 79, 484.

20. Malmgren, R. A., Bennison, B. E., and McKinley, T. W. The effect of guanazolo on antibody formation. J. nat. Cancer Inst. 1952, 12, 807.

21. Dutton, R. W., Dutton, A. H., and George, M. Effect of 8-azaguanine on antibody synthesis in vitro. Nature (Lond.) 1958, 182, 1377.

22. Davidson, J. D., and Freeman, B. B. The effects of antitumor drugs upon $\mathrm{P}^{32}$ incorporation into nucleic acids of mouse tumors. Cancer Res. 1955, 15, 31.

23. Skipper, H. E. On the mechanism of action of 6-mercaptopurine. Ann. N. Y. Acad. Sci. 1955, 60, 315.

24. Elion, G. B., Bieber, S., and Hitchings, G. H. The fate of 6-mercaptopurine in mice. Ann. N. Y. Acad. Sci. 1955, 60, 297.

25. Elion, G. B. Discussion in Ciba Foundation Symposium on The Chemistry and Biology of $\mathrm{Pu}$ - rines, G. E. W. Wolstenholme and C. M. O'Connor, Eds. Boston, Little, Brown and Co., 1957, p. 297.

26. Elion, G. B., and Hitchings, G. H. Biochemcial effects of 6-mercaptopurine in Ciba Foundation Symposium on The Chemistry and Biology of Purines, G. E. W. Wolstenholme and C. M. O'Connor, Ed. Boston, Little, Brown and Co., 1957, p. 286.

27. Elion, G. B., Singer, S., and Hitchings, G. H. The purine metabolism of a 6-mercaptopurine-resistant Lactobacillus casei. J. biol. Chem. 1953, 204, 35.

28. Elion, G. B., and Hitchings, G. H. Metabolism of 8- $\mathrm{C}^{14}$ adenine by a 6-mercaptopurine-resistant strain of Lactobacillus casei. Fed. Proc. 1954, 13, 203.

29. Elion, G. B., and Balis, M. E. Effect of 6-mercaptopurine on the interconversion of purine moieties in Lactobacillus casei. Fed. Proc. 1955, 14, 207.

30. Friedkin, M. The enzymic synthesis of 6-mercaptopurine deoxyriboside. Biochim. biophys. Acta $1955,18,447$.

31. Biesele, J. J. Antagonistic effects of 6-mercaptopurine and coenzyme $\mathrm{A}$ on mitochondria and mitosis in tissue culture. J. biophys. biochem. Cytol. $1955,1,119$.

32. Kaplan, N. O., Goldin, A., Humphreys, S. R., Ciotti, M. M., and Stolzenbach, F. E. Pyridine nucleotide synthesis in the mouse. J. biol. Chem. 1956, 219, 287.

33. Webster, G. C., and Johnson, M. P. Effects of ribonucleic acid on amino acid incorporation by a particulate preparation from pea seedlings. J. biol. Chem. 1955, 217, 641.

34. Zahl, P. A., and Albaum, H. G. Effect of aminopterin and certain purine antagonists on adenine nucleotide levels in tissues of tumor-bearing mice. Proc. Soc. exp. Biol. (N. Y.) 1955, 88, 263.

35. Hochstein, P. Synergistic effects of 6-mercaptopurine and methotrexate on anaerobic glycolysis by subcellular fractions of 591 mouse melanoma. Proc. Amer. Ass. Cancer Res. 1957, 2, 214.

36. Burk, D., Hochstein, P., Hunter, J., Landau, B., Laszlo, J., Wight, K., and Woods, M. A rationale of cancer chemotherapy based on primary inhibitions of glucose phosphorylation (hexokinase reaction) at substrate, coenzyme, and enzyme levels. Acta Un. int. Cancr. 1958, 14, 66.

37. Makinodan, T., and Gengozian, N. Primary antibody response to a closely related heterologous antigen after varying doses of $\mathrm{X}$-radiation, and its significance to related biologic phenomena. J. Immunol. 1958, 81, 513.

38. Schwartz, R. Unpublished observations.

39. Heaney, R. P., and Eliel, L. P. Metabolic and cytochemical changes produced by 6-mercaptopurine in human acute leukemia. Cancer 1956, 9, 252.

40. Schwartz, R., Eisner, A., and Dameshek, W. The effect of 6-mercaptopurine on immune responses. Clin. Res. 1959, 7, 39. 